\title{
Promoting a participatory convergence in a Spanish context: an inter-university action research project using visual narrative
}

\section{Elia Fernández-Díaz, Carlos Rodríguez-Hoyos, Adelina Calvo Salvador, Gloria} Braga Blanco, Lorea Fernández-Olaskoaga \& Prudencia Gutiérrez-Esteban

To cite this article: Elia Fernández-Díaz, Carlos Rodríguez-Hoyos, Adelina Calvo Salvador, Gloria Braga Blanco, Lorea Fernández-Olaskoaga \& Prudencia Gutiérrez-Esteban (2019) Promoting a participatory convergence in a Spanish context: an inter-university action research project using visual narrative, Educational Action Research, 27:3, 362-378, DOI: 10.1080/09650792.2018.1546607

To link to this article: https://doi.org/10.1080/09650792.2018.1546607

\section{曲 Published online: 19 Nov 2018.}

\section{Submit your article to this journal ๘}

Џll Article views: 68

View Crossmark data ¿ 


\title{
Promoting a participatory convergence in a Spanish context: an inter-university action research project using visual narrative
}

\author{
Elia Fernández-Díaz (D) ${ }^{a}$, Carlos Rodríguez-Hoyos (D) , Adelina Calvo Salvador (Dª , \\ Gloria Braga Blanco (D) ${ }^{b}$, Lorea Fernández-Olaskoaga (D) and Prudencia Gutiérrez- \\ Esteban (iD ${ }^{\text {d }}$
}

aDepartment of Education, University of Cantabria, Santander, Spain; 'bepartment of Education, University of Oviedo, Oviedo, Spain; 'Department of Education, University of the Basque Country, San Sebastián, Spain; department of Education, University of Extremadura, Badajoz, Spain

\begin{abstract}
This article focuses on the deconstruction of an inter-university action research project that has allowed us to rethink our teaching and research, questioning the social, political and ethical dimensions of the university. Following the pre-assembly proposal to promote participatory convergence, organized within the framework of the $1^{\text {st }} \mathrm{Global}$ Assembly for Knowledge Democracy (2017), an action research process was implemented in order to generate systematic inquiry around the current situation of the university and the need to act and rethink our commitment to promoting changes in this context. We have reflected on the meaning of democratization, rethinking the pedagogical relationship with our students and how we critically commit them to promote activism. We generated an environment where we look for the meaning of our practices by means of a visual narrative which has enabled us to weave and identify our own biography and become aware of where we are and why we act in one way or another. We have also focused on the search for the meaning of our actions in relation to the community we belong to and how to deal with the challenges of social justice, encouraging collaboration with other networks in a wider inter-university framework.
\end{abstract}

\section{ARTICLE HISTORY}

Received 9 July 2018

Accepted 6 November 2018

\section{KEYWORDS}

Participatory action research; knowledge democracy; higher education; visual narrative; transformative learning and teaching

\section{Introduction}

Mercantilist and meritocratic tendencies mediate relationships in the current university context, contaminated by a modus operandi where utilitarianism prevails and knowledge that does not meet the requirements imposed by the generalized hegemonic standards of quality and excellence is not taken into account. Moreover, this situation generates competitive relationships which promote individual professional development and the recruitment of new students who are viewed as clients, to the detriment of democratic, activist and collective training processes (Groundwater-Smith and Mockler 2009). A performative audit culture and managerialism (Ball 2012; Cochran-Smith 2005; Comber and Nixon 2011; Smith et al. 2010a) reigns, reducing the development of actions to provide students with the tools 
required to reach self-fulfilment and participate actively and critically in the reconstruction of culture through a process based on the exchange of knowledge.

In order to rethink the role of the University in the current scenario, it is necessary to articulate processes that contribute to exposing the mechanisms of alienation that endorse the status quo described above. Through the deconstruction of actions which bind us and the perversely objectified ways of understanding, we can gain an awareness of our limitations and thus undertake disruptive actions that allow us to focus on liberation. Accepting the critical and non-neutral nature of knowledge, linked to the situation in which it is generated, requires knowing the interests of those it responds to 'in order to understand the links that exist between the development of scientific thought, the cultural context and the power structures of society' (Fals-Borda 1980, 72). In this regard, explaining this submission and indoctrination and what binds us to hegemonic ways of transmitting knowledge, allows us to approach other ways of learning with the objective of generating emancipatory practices that facilitate the transformation of the environment as well as knowledge linked to social problems which are not conditioned by formal issues in the university context.

Based on this emancipatory paradigm, in which the participatory action research (PAR) converges and coexists with other lines of research, movements and social groups, the practices surrounding knowledge democracy enable the redefinition of the production, storage and use of knowledge, thereby providing groups with the tools for transforming this unequal and unjust social order, inserting themselves in the reality of the group itself in order to provoke a debate about academic and popular knowledge. This situated and contextual thinking should distance itself from classic knowledge management formats focused on contents and topics, in order to integrate different forms of knowledge and wisdom that emerge from social interactions in a specific action scenario (Orrego 2014). A relational knowledge of reality is advocated in the face of totalized universalisms and lineal, progressive and economistic rationality (Escobar 2016; Estermann 2006). This involves assuming that the generation of knowledge addresses qualitative, celebrative, affective and ritual relationships where intersubjective complementarity and reciprocity are pursued. For this it is necessary to create counter-hegemonic alternatives to the construction of knowledge, seeking an ecology of knowledge that opposes this established, dualist and abysmal eurocentric thinking (Santos 2014).

In this search for new forms of knowledge, PAR arises as an option for contributing to the production of situated knowledge, assuming that the knowledge generated in each context is an experiential knowledge, encompassing a philosophy of life, given that it requires commitment, an ethical stance and persistance at all levels (Fals-Borda and Anisur Rahman 1991). The transformation of the subjects in the participatory action research process, mediated by intersubjective, 'thinking-feeling' spaces, facilitates raising collective awareness, generated in the action itself (Fals-Borda 2001) which mobilizes the construction of knowledge linked to popular knowledge (Fals-Borda and Anisur Rahman 1991; Kindon, Pain, and Kesby 2007; Reason 1994).

\section{Toward a PAR to promote knowledge democracy and social justice in higher education: an approach from the literature review}

Recent studies continue to emphasize the role of AR in the emancipatory and participatory framework, contributing to social justice and knowledge democracy. Among the different 
contributions analyzed in the work of Vaugham and Burnaford (2016), we would like to highlight the contributions made on equity, the student voice and diversity in schools (Akom 2009; Blasco, Falco, and Munson 2006; Mclntyre 2003; Rogers et al. 2007; Sax and Fisher 2001), the transversal curricular treatment of equity (Capobianco, Horowitz, and CanuelBrowne 2004; Crookes and Chandler 2001; De Freitas 2008; Groenke 2010; Johnson and Button 2000) and student immersion in the context of the community both for learning critical content (Blasco, Falso, and Munson 2006) and also for producing social change despite contextual limitations (Crocco, Faithfull, and Schwartz 2003). Along the same lines, some studies also stand out for their contributions to identifying situations of inequality and strategies for promoting change, the search for social justice (Storms 2013) or the improvement of pedagogical relationships (Rogers et al. 2007), among other areas of intervention.

Likewise, the work of Gibbs et al. (2017) demonstrates the contributions to promoting social change by large scale studies (Lorenzetti and Walsh 2014; Miskovic and Hoop 2006; Thomas 2000), together with other more local experiences in the university and community context (Millican 2014; Smith et al. 2010a; Weber 2011). It also includes contributions by other works focused on analyzing the vicissitudes and opportunities in this neoliberal and tayloristic framework (Greenwood 2007) as well as the need to act against the domestication of educational action research, prioritizing the goal of transforming the social, cultural, discursive and material conditions in which these practices take place (Kemmis 2006; Smith et al. 2010b).

In addition to the literature reviews mentioned earlier, it is important to highlight recent thinking with regard to knowledge mobilization and action research in a global context (Rowell 2017), in which the emancipatory commitment of PAR and the need to find transformation processes that respond to the problems arising outside the Western context are reiterated (Chambers and Balanoff 2009; McTaggart 1993; Ravitch et al. 2017). This same premise should guide the configuration of international consortiums and networks (Rowell and Shosh 2016) in such a way that the contributions of research resulting from cross-cultural collaborations help provide tools to those who find themselves marginalized and disempowered (Kapoor and Jordan 2009; Rowell and Hong 2017) use the dialogue of popular and indigenous knowledge in order to implement research processes that pursue an ecology of knowledge.

In short, there is a need to rethink PAR as democratic disruption (Anderson 2017) and direct knowledge mobilization to achieve knowledge democracy (Hall and Tandom 2017), change structures and public policies, diversify and increase transformative itineraries providing them with greater activism (Thomson 2015) as well as continuing to promote resources for hope (Hardy, Salo, and Rönnerman 2015). Currently there is a need for PAR to emphasize its 'subversive, radical and oppositional' character, to reveal participatory academic research which has arisen from this, offering an alternative to the positivist hegemonic tradition, placing individuals and groups under unequal conditions at the centre, being sensitive to the initiatives of different groups, rethinking the value of the contributions that have emerged from outside academia, such as activist research and indigenous research methodology (Jordan and Kapoor 2016).

\section{Rethinking knowledge democracy within university teaching practice}

In an education system which is increasingly defined by its homogenizing and institutionalizing tendencies, we need to assert the political, social and ethical dimensions of the University through models of reflection capable of combatting the 
dominance of scholarly productivity (Rowell and Hong 2017) and the reproduction of decontextualized learning situations which are hardly emancipatory or disruptive (Giroux 2016).

In the Spanish university context, the reforms that have taken place within the framework of the convergence of the European Higher Education Area (EHEA) have oscillated under the influence of neoliberal policies. Thus far from providing a scenario for rethinking teaching practice in accordance with community needs, they have contributed to giving a certain degree of modernity to the approach of the underlying indoctrination which enhances the role of students as consumers of academic tasks disconnected from their professional and life project and increasing job insecurity in the teaching community.

Curricula are encouraging the parcelled construction of knowledge and an abysmal disconnection between theory and educational practice which relegates the questioning of the role of the teacher and student. In this climate of individualist work, perpetuated by the policy assesments of individual promotion, asceptic pedagogical relationships are generated which make it difficult for the university to respond to the undeniable social commitment which it must assume, that is, the need to try to improve the society which this institution claims to serve.

Taking into account the Spanish university scenario described above, we consider it a priority to rethink university teaching practice along the lines of a model of participatory responsibility based on social connection, through action research. A shared responsibility that requires the activism of everybody in order to be able to exert influence jointly, acting in the face of the maintenance of the processes that cause injustices, generating practices that enable us to understand the structural relationships in which situations of injustice are produced and to become aware of our role in transformation through collective action (Feldman, Bennett, and Vernaza-Hernandez 2015; Young 2011). Precisely, one of the main characteristics that define PAR is 'the collective way in which knowledge is produced, and the collectivization of this knowledge' (Fals-Borda and Rodríguez Brandao 1987, 18).

The pedagogical strategies that allow students to identify situations of social injustice and look for solutions so that people can reach their full potential in a profoundly unequal world need to be reconsidered from a participatory perspective. We have to rethink the pedagogical relationship systematizing shared inquiry processes so that our students can develop a comprehensive and complex vision of reality, addressing existing relations between the different contexts of the planet, the permanent dialectic between the local and the global, the differences and similarities of the problems which all societies and minority groups need to face, amongst other aspects (Fernández-Díaz, Rodríguez-Hoyos, and Calvo 2018).

This implies accepting that, far from maintaining the tendency for aseptic relationships built on systematic procedures typical of Western university contexts (Noddings 1996), the transformation of the pedagogical relationship must materialize provoking the questioning of our actions, the acceptance of commitments outside our comfort zone (McLaughlin and Ayubayeva 2015; Salzberger-Wittenberg, Henry, and Osborne 1983) and the rethinking of the role of the student and teacher in the current scenario.

On the one hand, rethinking the teaching role in the context of initial training, implies converting our own practices into a model that allows students to adequately assimilate the meaning of politically committed practices with the pursuit for social justice, maintaining close links with teachers who work within and outside the university and with other professionals who try to respond to injustices outside schools (Zeichner 2010). On the other hand, it implies 
involving students in researching the disruptive actions we develop to promote activism and their participation in the design of the subject and the educational materials that contribute to subverting power relations, so that they can experience transformation scenarios during their initial training (Cohen 2013; Crawford-Garrett et al. 2015; Dreier, Mollenkopf, and Swanstrom 2004; Feldman 2007; Lynn and Smith-Maddox 2007; Price 2001).

Finally, it is necessary to experiment with different languages and formats in order to facilitate free expression and break away from the dominance of written language by generating knowledge through methodological innovation (Fals-Borda 2001). Within this context, the relevance of the interactions that mediate the construction of meanings are explained, moving away from the application of stereotyped methodologies to confer the process of an experiential character, which is urgently required in the academic world. Thus, moving from a critical thinking generated from a hegemonic logic to a criticality mediated by circumstances (Deleuze and Guattari 2008).

\section{Designing the inter-university action research process}

\section{Context and aims}

The action research project in which we are now immersed began the 2016/2017 academic year with the creation of a scenario for promoting participatory convergence between university teachers from different Spanish Schools of Education: Cantabria, Oviedo, Extremadura and The Basque Country.

Taking into account the proposal of the $1^{\text {st }}$ Global Assembly for Knowledge Democracy (June 2017, Cartagena, Colombia) our contribution was to move the reflections generated in the process of meeting and discussion to a virtual format, replicating in our specific context, the cohesive profile of diverse perspectives that underline the purpose of the assembly. Within this context, we began an interuniversity action research project, in which we are currently involved, with the aim of including our university students, in order to contribute to reinterpreting the social, political and ethical dimensions of the university according to a model of participatory responsibility based on social connection.

Given this general goal, we formulated a series of specific objectives to implement the actions focused on generating systematic inquiry around the current situation of the University and rethinking our commitment to promoting changes in the environment throughout all the phases in which our interuniversity action research is developed. Thus, we aimed to:

- generate a communicative space to explain the limitations of our university teaching practice in the current context of commercialization;

- rethink the pedagogical relationship and the construction of knowledge according to a model of participatory responsibility;

- integrate the visual narrative with the objective of encouraging experimentation with emerging emancipatory methodologies, highlighting the limitations and controversies of the process of reflection on action. 


\section{Phases and actions}

We began the first phase of awareness about knowledge democracy with the design of the pre-assembly workshop, focused on promoting a participatory convergence in our work with the objective of generating a collaborative work environment for redefining our teaching practices. After looking into different methodological approaches, from a critical perspective of participatory research, we selected the topics with which we can identify in terms of the points of discussion raised in the proposal of the assembly and contextualized them according to our interests and needs (shown in Fig. 1). In order to collaborate in the construction of a discussion space and facilitate asynchronous participation, we suggested creating an area for collaborative reflection on the issues previously mentioned using different formats, according to the various opportunities for participation available and taking into account all the concerns and interests of those involved. This phase finishes with the presentation of our conclusions and constributions to the pre-assembly CARN workshop.

The second phase was focused on carrying out actions to transform our teaching practice, promoting activism in conjunction with our students. The actions designed in this work environment are directed at systematizing a shared inquiry in relation to a model of responsibility based on social connection and the collective and democratic construction of knowledge. Throughout this process, we aim to give the research process more methodological depth, by questioning ourselves about how we are attempting to respond to the questions we share in the workshop, reflecting on the commitments that are assumed based on the analysis of practices, the pedagogical meeting spaces generated as well as the resources produced in our collaborative work environment and integrating the improvement proposals in order to continue making progress. More specifically, the following actions were developed:

- involvement of students in actions designed to promote activism; educational resources produced by students using visual narrative;

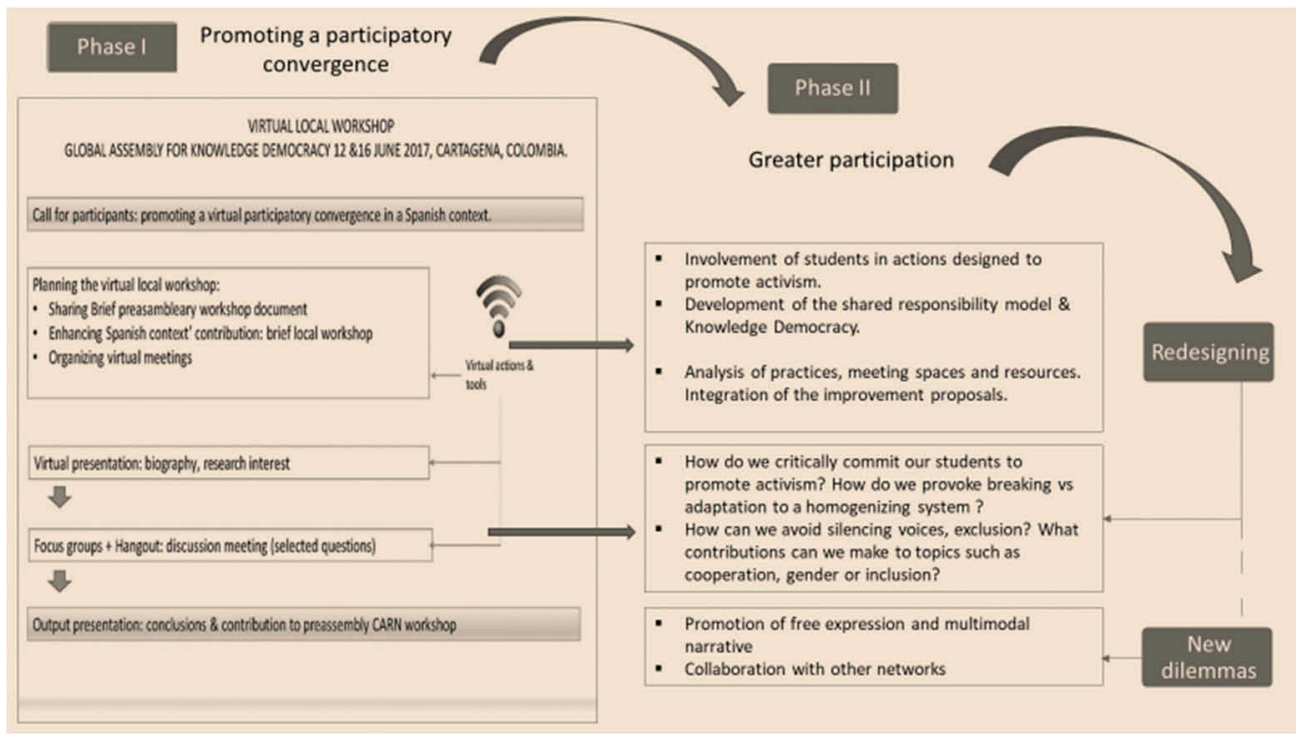

Figure 1. Designing the inter-university action research process. 
- development of the shared responsibility model and knowledge democracy;

- analysis of practices, meeting spaces and resources. Integration of the improvement proposals.

\section{Data collection and analysis}

With regard to the techniques for data collection and production, together with the use of diaries, interviews and the focus group, other specific techniques stand out for generating visual narratives such as micro-narratives and dialogues stimulated by audiovisual methods (Lewthwaite and Nind 2017). With respect to the analysis of information, a deductiveinductive process of reflection is carried out around the dimensions that arise from the conceptual axes from the literature review as well as the implementation of the process in an attempt to respond to the preliminary investigative questions and integrate the dilemmas which have been emerging as a result of the actions undertaken. The dimensions of the analysis used were developed following in the footsteps of other works focused on exploring the transformational potential of narratives (Rivas et al. 2016; Sparkes and Smith 2008):

- Knowledge democracy as a principle procedure: genesis of the communicative space.

- Reconstructing our ways of doing and being: moving toward relational and experiential knowledge.

- Promoting development against our comfort zone: dilemmas and new decisions to promote activism.

The following figure contains a summary of the methodological design of the process:

\section{Reflection on the action}

Although, this paper presents the results of first phase of our action research, focusing on the process of reflection by university teachers (UT), we are also providing the results of our first actions developed around knowledge democracy.

\section{Knowledge democracy as a principle procedure}

During the initial phase, in which participatory convergence is promoted, the use of different languages and formats enabled us to generate a communicative space favouring free expression and discussion in relation to our own university education experiences. In this work environment we reflect on knowledge production processes in our university context with the aim of redefining the procedural principles which preside over our actions and disruptions in the formation of transformative critical subjects:

In 2015 I had the opportunity to visit an exhibition in the Reina Sofía Museum called Really useful knowledge. It challenged us to think about the curriculum we have and the one we want to have, based on the idea of the curriculum as a space of identity (as stated by Tadeu Da Silva). What knowledge do we consider useful at university? Can we 
talk about usefulness without falling into an economist and simplistic way of thinking? (UT4).

For me it is fundamental for students to feel uncomfortable and "unbalanced", because this situation provokes the search for balance and reconstruction. It's not easy but training critical people capable of analysing and creating their own identity and their own knowledge remains in our hands. It has been very interesting, and I will look deeper into this in order to work on this with students next year (UT3),

Yes, I think we can talk about "useful" or functional knowledge in universities, distancing ourselves from the use of mercantilism and concern about efficiency. In my opinion, pedagogical knowledge about our disciplines is functional if it is embedded in real pedagogical practices, permitting us to analyse them, unravel them and reveal their contradictions... If it allows (more or less helps or even "obliges" or "forces") students to question themselves, it places them before intellectual, professional, institutional, personal contradictions... it makes them take risks, feel confusion sometimes or stupor, it provokes curiosity. In this case, knowledge is useful and functional for me (UT2; focus group_session 3_2017).

This communicative space has allowed us to reflect on the rigidities that surround the generation of knowledge in our context of action and on the barriers in order to change our teaching practice into a disruptive and situated one. We began to create an intersubjective space mediated by contextual singularities, generational differences and specific experiences in which we redefined the meaning and functionality of knowledge and actions related to its production. In this process we also became aware of the limitations of an institutionalized context which leaves out the pleasure and risk of learning, which is not outside the students' lives, given that many other non-formal contexts allow them to develop relevant life lessons:

My experience tells me that students regard their academic development more and more like the progressive overcoming of levels of a videogame not as a life experience in any way. I feel that learning has been "bureaurocratized" and "automated", that students only do what they need to, and only that in order to obtain an academic result but with very little or no personal involvement in the process, undoubtedly because they don't understand or share the interest of what we propose to them (UT4_story_2017).

Faced with the continuity of routines and the perpetuation of isolation in the university context, we try to rethink the actions that facilitate the production of knowledge in which power relations are subverted, through practices that allow students to take control of the process, interweaving inquiry and critical reinterpretation of the information in real experiences in which they are building their teaching identity. In our reflection on the projects we have developed with schools to promote social transformation we can identify the relevance of experiential knowledge:

In the way in which this knowledge is generated, offering transformative practices matters, always connected to the reality of the classroom, separate to the experiences lived in the Practicum...sometimes they are "boxed in" because they are limited to carrying out actions that are expected of them in the "Practicum Guide" (UT6_story_2018).

The image I am now showing you demonstrates the experience that we carried out with Year 6 students in a nearby primary school. My students organised workshops thinking about important work that needs to be done with students (...) The title of the workshop, Izan Morea, (which in Basque means "Being Purple") is an invitation to work on gender roles. We all take for granted that equality and discourse is interiorized but in practice the 
students realized that there is still a long way to go. Personally, it gives me great satisfaction to offer students the chance to spend time with the children involved and feel responsible for them in the workshop because they begin to transform their role as a student to one of being a teacher for a few hours (UT5_story_2018).

\section{Reconstructing our ways of doing and being}

In this inquiry environment, we continue explaining the need to transform pedagogical relationships, analyzing the space and time that facilitate the genesis of relational knowledge, in which diverse emotional states are taken into account. An intense debate was generated around the urgency to break existing barriers, we asked ourselves what type of disruptive situations favour the search for an expanded classroom and where to prioritize links; spaces where we converse considering individualities, spaces where we are heard, in order to feel this ' $\mathrm{I}$ ' which is transformed and progresses with the group.

This is a significant image because it suggests a clear difference between how to look for solutions to problems and how to make the group focus and move forward. It is exactly a group of this size which really excites us and when really interesting topics arise, this is when the roles of the teacher and student converge following the same direction. It is a space where each individual can be themselves and reflect on the role of the teacher. There have been few moments like this during this academic year. Curiously these moments are achieved outside the conventional classroom environment (UT3_story_2017).

For me, the photo is very significant because this year I have found myself in a situation of transition which allows me to carry out all the classes as dialogues and we sit in a circle. I believe my next step will be to leave the classroom and occupy other spaces further away from the classroom (as shown in the photo). All this is helping me to think about what educational practices are provided in the spaces we have. (UT1_story_2017).

On the other hand, the shared analysis of open practices, in which students actively participate together with other groups, helps us to advance in the interpretation of the relational aspect of knowledge as well as the need to rethink our commitments with respect to educational and social change:

\footnotetext{
New pedagogical relationships, from a teacher-student relation, we move to a person-person connection...We show how we really are at an affective and relational level and this is how our deep-rooted visions and emotions emanate about what meanings we give to being a teacher. Here our social commitment, the need to transform through participation and being capable of seeing our students as teachers, both from an educational and personal perspective is revealed (UT6_story_2018).
}

The intersubjective spaces in which we are deconstructing this collective knowledge, mediate the reconstruction of our own teaching identity, outlining the role that we want to play in the actions carried out for generating changes in our environment, according to a model of shared responsibility. The reflections on the implications of this experience in our teaching work take this into account:

Participating in the workshop has put me in a specific context and place. Teaching commitment is accompanied by the commitment by the students as well, in which there is no point in this relation being one of active object and the other passive (...) I have spoken openly with the students, inviting them to say what they think, but above all, I have asked them to question everything that is 
suggested to them, and, in addition, to do it aloud. I have shown my side of not knowing, my side where I don't know all the answers. . It's an invitation to the students to encourage them to think, react and for them to get together among themselves and above all, for them to become subjects who act (UT5_story_2018).

\section{Promoting development against our comfort zone: dilemmas and new decisions to promote activism}

Throughout the research process, we reconstruct ourselves as transformative critical subjects, redefining accepted commitments in order to assume the model of shared responsibility based on the discussion of our experiences. We jointly design actions to respond to local needs, while immersed in global problems, with the aim of encouraging the construction of a teaching identity in our students that favours inclusive, democratic and plural schools.

Reflection on the techniques implemented to facilitate free expression, using different languages and formats, has allowed us to identify the findings on the improvement of participation and the transformation of our practices to promote activism in students and teachers, as well as the dilemmas and vicissitudes to be able to guide improvements in the next cycle of action.

The integration of the visual and transmedia narrative provides us with the opportunity to experiment with innovative emancipatory methodologies that seek to increase the opportunities for student participation in the production of educational resources committed to denouncing situations that perpetuate social injustice, as is shown in the following figure 2 .

On the other hand, the stimulation of dialogue through audiovisual resources generated by teachers in the work environment has facilitated taking a deeper look

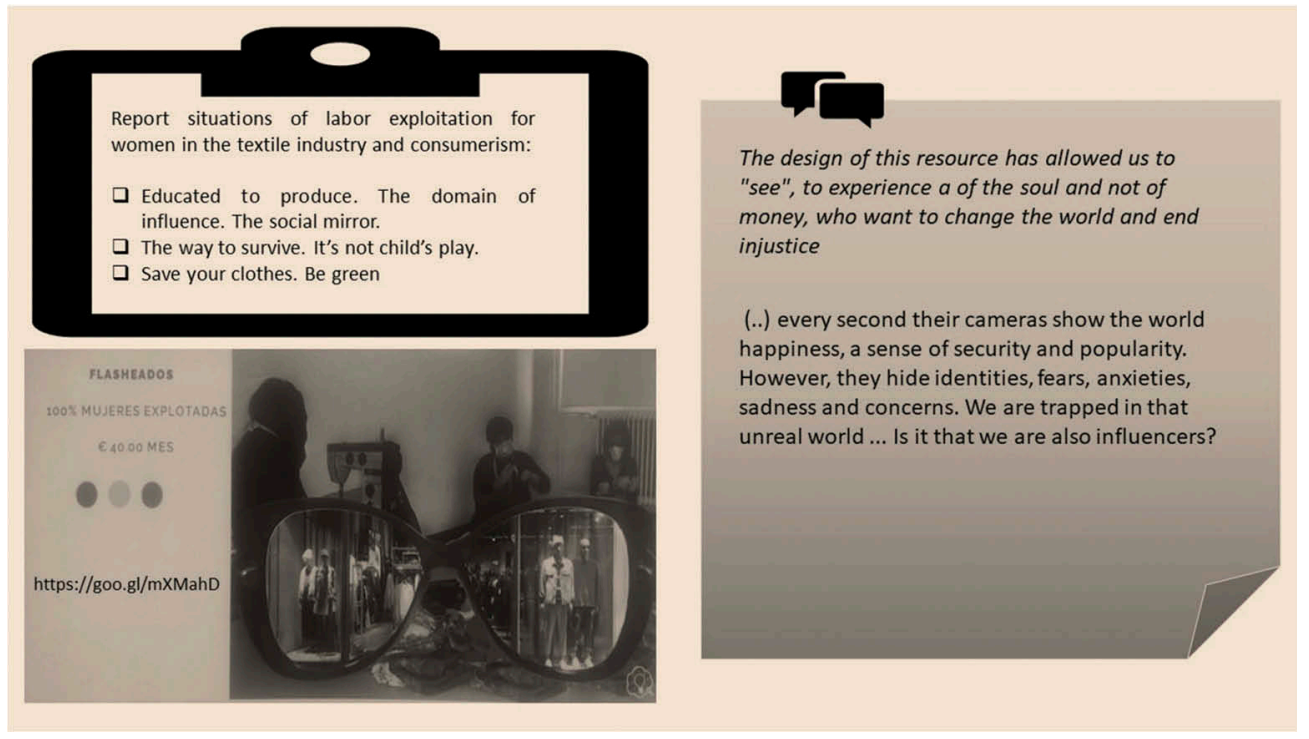

Figure 2. Consciousness: educational resource produced by student using visual narrative. 
at the constraints and dilemmas related to knowledge democracy and social justice within our context of action (figure 3).

Despite the advances described, we continue to perceive a certain reticence in our students who tacitly suggest the perpetuation of the indoctrination received during

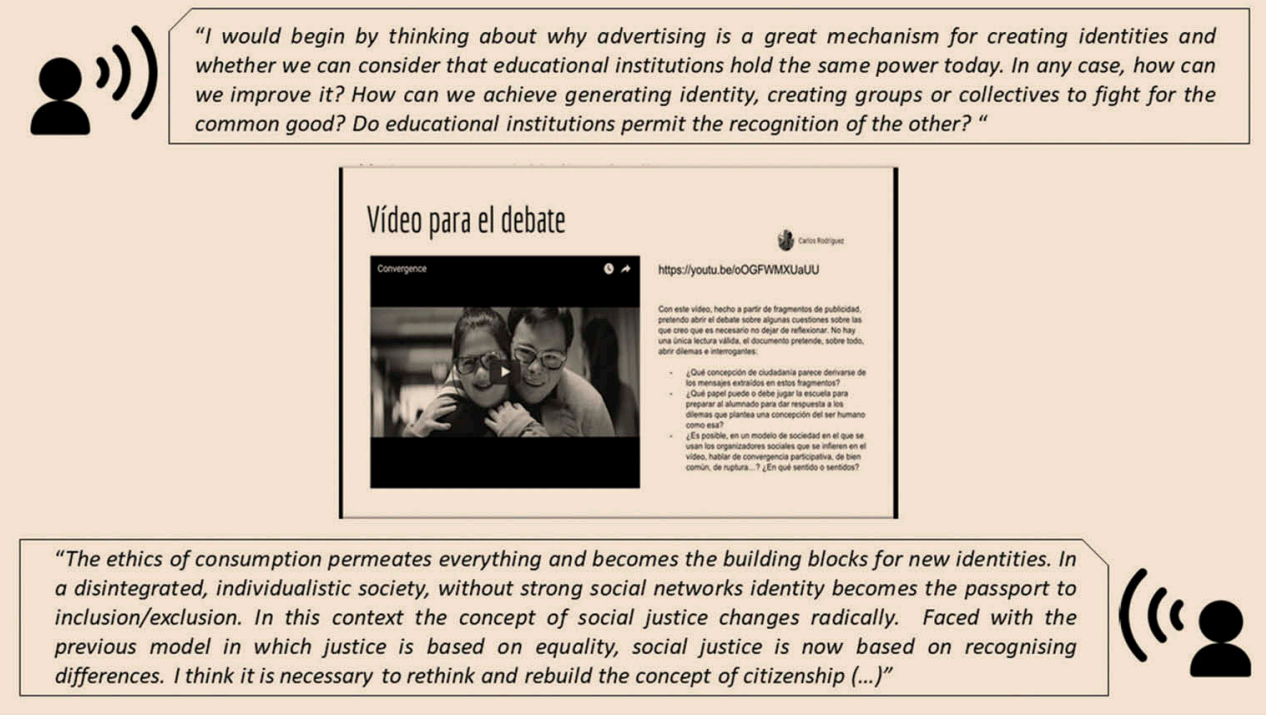

Figure 3. Teacher voices using visual narrative to produce knowledge in a relational, complementary and reciprocal way.

compulsory education. Nevertheless, the joint deconstruction of the narratives in the intersubjective spaces makes us aware of the path that lies ahead, conferring potential for change to the extent that we try to identify the framework required for enabling other forms of thinking, acting and being in the current university context:

This part is the most difficult, making sure that the commitment of new generations towards change comes from their initiative and not from the supervision of somebody. I think this is the consequence of the school system which punishes movement and the ability to act; it encourages dependence on the adult-expert; it kills desire and motivation and destroys youthful action (UT1_story_2018).

I believe that from my daily practice, I must resist the naturalization of the discourses that surround this strong competitiveness. Those who have grown up in a different University and have more historic perspective must build strong community relations and solidarity with younger teachers where the dominant discourses can be debated and rebuilt, substituting them with others much more focused on the common good (UT4_story_2018). 


\section{Conclusion}

The initial results show the improvements that have been achieved so far. As a result of this action research, we generated an environment where we look for the meaning of our practices by means of a visual narrative which allows us to weave and identify our own biography and the awareness of where we are and why we act in one way or another; the search for the meaning of our actions in relation to the community we belong to and how to deal with the challenges of social justice.

Firstly, we have been able to clarify the context of meritocratic and dehumanized action itself, where there is a proliferation of the promotion of good practices linked to the criteria of effectiveness and production, far from a university committed to social justice and one in which we as teachers find ourselves immersed, representing a role of 'dehumanized objects, powerless bystanders or aimless observers' (Feldman, Bennett, and Vernaza-Hernandez 2015, 96). In this regard, action research has allowed us to question ourselves and our own university practice (Drummond 2008). Following a period in which we have cultivated an open communicative space (Habermas 1984), characterized by reciprocity and mutual accompaniment focused on promoting critical thinking (Abma et al. 2017), we have become aware of the different discourses, our professional background and the social and political context in which they have developed. In this scenario of participatory convergence, we have reflected on the meaning of democratization, rethinking the pedagogical relationship with our students and how we critically commit them to promote activism, how we provoke breaking vs. adaptation to a homogenizing system that supports competitiveness while ignoring social commitment or the contributions we make to topics such as cooperation, gender or inclusion. This communicative space has allowed us to actively participate in the production of knowledge and also generate actions to enable the transformation of the subjects involved in the research (Fals-Borda 2001), to the extent that we have been able to consolidate our commitment to systematizing a dialogue and confrontation with the hegemonic monoculture and recognize the continuous and dynamic connections between different knowledge, raising our awareness of the imperative need to integrate the absent voices in our university context.

Secondly, we have reflected on actions in order to contribute to the development of greater social justice, acting to eliminate the barriers of oppression and institutional domination (Young 2011) that unconsciously surround routine university practice. Thus, we rethink teaching practice within the framework of a research process capable of prioritizing the generation of actions and the construction of knowledge based on experiences which are relational, developing a new pedagogical relationship interwoven with feelings, knowledge and action (Holland 2007). The actions developed in this scenario of shared responsibility have contributed to improving pedagogical strategies so that students can identify situations of social injustice, question existing practices and look for solutions, such as the elaboration of educational resources using visual narrative to promote activism, among others.

In the research process, we carried out a contextualized historic, social and cultural deconstruction of our practices and thinking (Etherington 2007; McArdle et al. 2015), through a moral and political practice of reflection on our university teaching identity and the repercussions on students. Furthermore, since we are what we narrate 
(Clandinin and Connelly 2000), our narratives have allowed us to take a deeper look at the meaning of what we do, while reconstructing ourselves by collaboratively investigating the transformation process itself (Adams 2008; Kouritzin, Piquemal, and Norman 2009), expanding and diversifying conventional forms of narrative inquiry, with the aim of creating new meanings and relationships (Cole and Knowles 2008; Pink 2001).

The use of the narrative visual in the production and analysis of data constitutes a tool for increasing reflection on the improvement of participatory culture in the university context and actions aimed at responding to situations of social injustice. In this regard, we have experimented with different emerging emancipatory methodologies in order to contribute to revealing the conditions of the university context, attempting to integrate absent voices to generate knowledge based on different perspectives and interpretations which counter the linear, monologic and teleological tendency of the current context (Crimmins 2017). Thus, we managed to contribute to reinforcing a criticality mediated by experiences, facilitating the free expression of the subjects participating in the research process (Santos 2006).

Finally, we are not only able to integrate improvements in our teaching practice but also in the process of action-research itself. Although we have managed to involve the students in the research of disruptive actions developed to encourage activism, using different languages and formats, we have demonstrated the limitations and critical incidents that will allow us to improve strategies for optimizing the participation of students in the communicative space, so that they can feel and live the research process as exciting companions (Mounter 2007). In addition to recognizing the need to promote the integration of their voices in the deconstruction of the research process, we have become aware of the urgent need to continue progress with the purpose of erradicating the inherent difficulties and controversies of the hegemony of written discourse in the design of our subjects and in university community life. Furthermore, we have carried out research together with our students in order to promote free expression and multimodal narrative (Bognar and Zovko 2009).

We believe that it is necessary to reconsider actions to promote collaboration with other networks to share experiences in a wider inter-university framework. Likewise, we need to continue asking ourselves how to give situated responses to local needs, while at the same time being immersed in mactrocontextual problems. Based on the review of the dilemmas that have concerned us we have proposed improvements we consider appropriate to continue the next cycle of action-research, given that the perception of knowledge as a wandering through fields of intertextual subjectivities forces us to constantly shift our position (Rogoff 2006).

\section{Disclosure statement}

No potential conflict of interest was reported by the authors.

\section{ORCID}

Elia Fernández-Díaz (D) http://orcid.org/0000-0003-0647-260X

Carlos Rodríguez-Hoyos (D) http://orcid.org/0000-0002-6949-6804 
Adelina Calvo Salvador (iD http://orcid.org/0000-0002-9262-7905

Gloria Braga Blanco (D) http://orcid.org/0000-0003-4389-4908

Lorea Fernández-Olaskoaga (iD http://orcid.org/0000-0001-5059-5143

Prudencia Gutiérrez-Esteban (iD) http://orcid.org/0000-0001-5328-5319

\section{References}

Abma, T.A., T. Cook, M. Rämgård, E. Kleba, J. Harris, and N. Wallerstein. 2017. "Social Impact of Participatory Health Research: Collaborative Non-Linear Processes of Knowledge Mobilization." Educational Action Research 25 (4): 489-505. doi:10.1080/09650792.2017.1329092.

Adams, T. 2008. "A Review of Narrative Ethics." Qualitative Inquiry 14 (2): 175-194. doi:10.1177/ 1077800407304417.

Akom, A.A. 2009. "Critical Hip Hop Pedagogy as a Form of Liberatory Praxis." Equity and Excellence in Education 42 (1): 52-66. doi:10.1080/10665680802612519.

Anderson, G. 2017. "Participatory Action Research (PAR) as Democratic Disruption: New Public Management and Educational Research in Schools and Universities." International Journal of Qualitative Studies in Education 30 (5): 432-449. doi:10.1080/09518398.2017.1303211.

Ball, S. 2012. "The Making of a Neoliberal Academic." Research in Secondary Education 2 (1): 29-31.

Blasco, P.M., R.A. Falco, and L.J. Munson. 2006. "Project SELF: Preparing Professionals to Facilitate Self-Determination." Journal of Early Intervention 29 (1): 63-79. doi:10.1177/105381510602900105.

Bognar, B., and M. Zovko. 2009. "Pupils as Action Researchers: Improving Something Important in Our Lives." Educational Journal of Living Theories 1 (1): 1-49.

Capobianco, B., R. Horowitz, and D. Canuel-Browne. 2004. "Action Research for Teachers." Science Teacher 71 (3): 48-53.

Chambers, C.M., and H. Balanoff. 2009. "Translating 'Participation' from North to South: A Case against Intellectual Imperialiam in Social Science Research." In Education, Participatory Action Research, and Social Change: International Perspectives, edited by D. Kapoor and S. Jordan, 73-88. New York: Palgrave Macmillan.

Clandinin, D.J., and F.M. Connelly. 2000. Narrative Inquiry: Experience and Story in Qualitative Research. San Francisco: Jossey-Bass.

Cochran-Smith, M. 2005. "The Politics of Teacher Education and the Course of Complexity." Journal of Teacher Education 56 (3): 181-185. doi:10.1177/0022487105276411.

Cohen, A. 2013. Justice in the City: An Argument from the Sources of Rabbinic Judaism. Boston, MA: Academic Studies Press.

Cole, A.L., and G.L. Knowles. 2008. "Arts Informed Research." In Handbook of the Arts in Qualitative Research. Perspectives, Methodologies, Examples and Issues, edited by G.J. Knowles and A.L. Cole, 55-70. Los Angeles, CA: Sage.

Comber, B., and H. Nixon. 2011. "Critical Reading Comprehension in an Era of Accountability." Australian Education Researcher 38: 167-179. doi:10.1007/s13384-011-0022-z.

Crawford-Garrett, K., S. Anderson, A. Grayson, and C. Suter. 2015. "Transformational Practice: Critical Teacher Research in Pre-Service Teacher Education." Educational Action Research 23 (4): 79-496. doi:10.1080/09650792.2015.1019902.

Crimmins, G. 2017. "How a Verbatim Drama Based on the Lived Experience of Women Casual Academics in Australia Resonated with Its Audience and Transformed a Narrative Inquiry into an Action Research Project." Educational Action Research 25 (3): 337-353. doi:10.1080/09650792.2016.1182042.

Crocco, M.S., B. Faithfull, and S. Schwartz. 2003. "Inquiring Minds Want to Know: Action Research at a New York City Professional Development School." Journal of Teacher Education 54 (1): 19-30. doi:10.1177/0022487102238655.

Crookes, G., and P.M. Chandler. 2001. "Introducing Action Research into the Education of Postsecondary Foreign Language Teachers." Foreign Language Annals 34 (2): 131-140. doi:10.1111/flan.2001.34. issue-2.

De Freitas, E. 2008. "Troubling Teacher Identity: Preparing Mathematics Teachers to Teach for Diversity." Teaching Education 19 (1): 43-55. doi:10.1080/10476210701860024. 
Deleuze, G., and F. Guattari. 2008. Mil Mesetas. Capitalismo Y Esquizofrenia [Thousand Plateaus. Capitalism and Schizophrenia].. Valencia: Pre - Textos.

Dreier, P., J.H. Mollenkopf, and T. Swanstrom. 2004. Place Matters: Metropolitics for the Twenty-First Century. Lawrence, KS: University Press of Kansas.

Drummond, M.J. 2008. "The Pain Must Go On. Review Essay." In Curriculum and the Teacher: 35 Years of the Cambridge Journal of Education, edited by N. Norris, 225-241. London: Routledge.

Escobar, A. 2016. Sentipensar Con La Tierra. Nuevas Lecturas Sobre Desarrollo, Territorio Y Diferencia [Tinking-Feeling with the Earth. New Readings on Development, Territory and Difference]. Medellin: ediciones UNAULA.

Estermann, J. 2006. Filosofía Andina. Sabiduría indígena para un mundo nuevo [Andean Philosophy. Indigenous knowledge for a new world]. La Paz: ISEAT.

Etherington, K. 2007. "Ethical Research in Reflexive Relationships." Qualitative Inquiry 13 (5): 599-616. doi:10.1177/1077800407301175.

Fals-Borda, O. 2001. "Participatory (Action) Research in Social Theory: Origins and Challenges." In Handbook of Action Research, edited by P. Reason and H. Bradbury, 27-31. London: Sage Publications.

Fals-Borda, O., and M. Anisur Rahman. 1991. Action and Knowledge: Breaking the Monopoly with Participatory Action Research. New York: Intermediate Technology Publications.

Fals-Borda, O. 1980. "La ciencia y el pueblo". [Science and the people]. In Investigación Acción Participativa: inicios y desarrollo [Participatory Action Research: foundations and development], edited by M. C. Salazar, 65-84. Madrid: Editorial Popular, OEl.

Fals-Borda, O., and C. Rodríguez Brandao. 1987. Investigación Participativa [Participatory Research]. Montevideo: De la Banda Oriental.

Feldman, A. 2007. "Teachers, Responsability and Action Research." Educational Action Research 15 (2): 239-252. doi:10.1080/09650790701314809.

Feldman, A., K. Bennett, and V. Vernaza-Hernandez. 2015. "Responsible Action Research for the Pursuit of Justice." Educational Action Research 23 (1): 85-103. doi:10.1080/09650792.2014.994014.

Fernández-Díaz, E., C. Rodríguez-Hoyos, and A. Calvo Salvador. 2018. "Transforming University Teaching: Participatory Action Research to Promote Disruptive Actions." In Participatory Action Research: Principles, Approaches and Applications, edited by J. Caller and J. Foletta, 177-197. CA: Nova Publisher.

Gibbs, P., P. Cartney, K. Wilkinson, J. Parkinson, S. Cunningham, C. James-Reynolds, T. Zoubir, et al. 2017. "Literature Review on the Use of Action Research in Higher Education." Educational Action Research 25 (1): 3-22. doi:10.1080/09650792.2015.1124046.

Giroux, E. 2016. "Higher Education and the Politics of Disruption." Frameworks: Education and Society 3: 15-26.

Greenwood, D.J. 2007. "Teaching/Learning Action Research Requires Fundamental Reforms in Public Higher Education." Action Research 5 (3): 249-264. doi:10.1177/1476750307081016.

Groenke, S.L. 2010. "Seeing, Inquiring, Witnessing: Using the Equity Audit in Practitioner Inquiry to Rethink Inequity in Public Schools." English Education 43 (1): 83-96.

Groundwater-Smith, S., and N. Mockler. 2009. Teacher Professional Learning in an Age of Compliance: Mind the Gap. Dordrecht: Springer.

Habermas, J. 1984. The Theory of Communicative Action: Vol. 1. Reason and Rationalization of Society. London: Heinemann.

Hall, B.L., and R. Tandon. 2017. “Decolonization of Knowledge, Epistemicide, Participatory Research and Higher Education." Research for All 1 (1): 6-19. doi:10.18546/RFA.01.1.02.

Hardy, I., P. Salo, and K. Rönnerman. 2015. "Bildung and Educational Action Research: Resources for Hope in Neoliberal Times." Educational Action Research 23 (3): 383-398. doi:10.1080/ 09650792.2015.1012175.

Holland, J. 2007. "Emotions and Research." International Journal of Social Research Methodology 10 (3): 195-209. doi:10.1080/13645570701541894.

Johnson, M.J., and K. Button. 2000. "Connecting Graduate Education in Language Arts with Teaching Contexts: The Power of Action Research." English Education 32 (2): 107-126. 
Jordan, S., and D. Kapoor. 2016. "Re-Politicizing Participatory Action Research: Unmasking Neoliberalism and the Illusions of Participation." Educational Action Research 24 (1): 134-149. doi:10.1080/09650792.2015.1105145.

Kapoor, D., and S. Jordan. 2009. "Introduction: International Perspectives on Education, PAR, and Social Change." In Education, Participatory Action Research, and Social Change, edited by D. Kapoor and S. Jordan, 1-11. New York: Palgrave Macmillan.

Kemmis, S. 2006. "Participatory Action Research and the Public Sphere." Educational Action Research 14 (4): 459-476. doi:10.1080/09650790600975593.

Kindon, S., R. Pain, and M. Kesby. 2007. Participatory Action Research Approaches and Methods: Connecting People, Participation and Place. Abingdon: Routledge.

Kouritzin, S., N. Piquemal, and R. Norman. 2009. Qualitative Research. New York: Routledge.

Lewthwaite, S., and M. Nind. 2017. The Approaches Used in Research Methods Teaching- NCRM Quick Start Guide. Manual. University of Southampton: National Centre for Research Methods (NCRM).

Lorenzetti, L., and C.A. Walsh. 2014. "Is There an ' $F$ ' in Your PAR? Understanding, Teaching and Doing Action Research." Canadian Journal of Action Research 15: 50-64.

Lynn, M., and R. Smith-Maddox. 2007. "Pre-Service Teacher Inquiry: Creating a Space a Dialogue about Becaming a Social Justice Educator." Teaching and Teacher Education 23 (1): 94-105. doi:10.1016/j.tate.2006.04.004.

McArdle, K., J. Birchley, J. Bruce, A. Hurrell, S. Paterson, and M. Stephen. 2015. “When Practice Takes Precedence: Conceptions of Inquiry and the Link to Ethical Posture." Educational Action Research 23 (1): 68-84. doi:10.1080/09650792.2014.887026.

McIntyre, A. 2003. "Participatory Action Research and Urban Education: Reshaping the Teacher Preparation Process." Equity and Excellence in Education 36 (1): 28-39. doi:10.1080/10665680303497.

McLaughlin, C., and N. Ayubayeva. 2015. "It Is the Research of Self Experience': Feeling the Value in Action Research." Educational Action Research 23 (1): 51-67. doi:10.1080/09650792.2014.994018.

McTaggart, R. 1993. "Dilemmas in Cross-Cultural Action Research." In Health Research in Practice: Political, Ethical and Methodological Issues, edited by D. Colquhoun and A. Kellehear, 65-96. New York: Springer.

Millican, J. 2014. "Higher Education and Student Engagement: Implications for a New Economic Era." Education and Training 56: 635-649. doi:10.1108/ET-07-2014-0077.

Miskovic, M., and K. Hoop. 2006. "Action Research Meets Critical Pedagogy: Theory, Practice, and Reflection." Qualitative Inquiry 12: 269-291. doi:10.1177/1077800405284367.

Mounter, J. 2007. "Can Children Carry Out Action Research about Learning, Creating Their Own Learning Theory?" Master Module Understanding Learners and Learning. University of Bath. Accesed August 15, 2018. http://www.actionresearch.net/writings/tuesdayma/joymounterull. htm.

Noddings, N. 1996. "Stories and Affect in Teacher Education." Cambridge Journal of Education 26 (3): 435-447. doi:10.1080/0305764960260311.

Orrego, I.A. 2014. "Educación Para El Desarrollo En Zapatos Latinoamericanos: Apuestas Epistémicas". [Education for Development in Latin American Shoes: Epistemic Issues]." In Pedagogía Praxeológica Y Social: Hacia Otra Educación [Praxeological and Social Pedagogy: Towards Another Education], edited by C. Juliao. Bogotá: Corporación Universitaria Minuto de Dios, 180257.

Pink, S. 2001. Doing Ethnography: Images, Media and Representation in Research. London: Sage Publications.

Price, J. 2001. "Action Research, Pedagogy and Change. The Transformative Potential of AR in Pre-Service Teacher Education." Curriculum Studies 33 (1): 43-74. doi:10.1080/00220270118039.

Ravitch, S.M., M.J. Tarditi, N. Montenegro, D. Baltodano, and E. Estrada. 2017. "Learning Together: Dialogue, Collaboration, and Reciprocal Transformation in a Nicaraguan Educational Program." In The Palgrave International Handbook of Action Research, edited by L.L. Rowell, C.D. Bruce, J. M. Shosh, and M.M. Riel, 791-805. US: Palgrave Macmillan.

Reason, P. 1994. "Human Inquiry as Discipline and Practice." In Participation in Human Inquiry, edited by P. Reason, 40-56. 
Rivas, J.I., A.E. Leite, Ma.J. Márquez, P. Cortés, Ma.E. Prados, and D. Padua. 2016. "Facebook as a Virtual Place to Share Learning between Groups of Students from Different Universities." RELATEC, Latin American Journal of Educational Technology 15 (2): 55-66.

Rogers, D., C.M. Bolick, A. Anderson, E. Gordon, M.M. Manfra, and J. Yow. 2007. "It's about the Kids: Transforming Teacher-Student Relationships through Action Research." The Clearing House 80 (5): 217-222. doi:10.3200/TCHS.80.5.217-222.

Rogoff, I. 2006. "Academy as Potentiality." In A.C.A.D.E.M.Y., edited by A. Nollert and I. Rogoff, 1320. Frankfurt am Main: Revolver.

Rowell, L. 2017. "Knowledge Mobilization and Action Research in Global Contexts: Towards a Comparative Orientation." Educational Action Research 25 (3): 333-336. doi:10.1080/096507 92.2017.1326759.

Rowell, L., and E. Hong. 2017. "Knowledge Democracy and Action Research: Pathways for the Twenty-First Century." In The Palgrave International Handbook of Action Research, edited by L. L. Rowell, C.D. Bruce, J.M. Shosh, and M.M. Riel, 63-83. New York: Palgrave Macmillan.

Rowell, L., and M.J. Shosh. 2016. "Editorial." Educational Action Research 24 (1): 1-3. doi:10.1080/ 09650792.2015.1132589.

Salzberger-Wittenberg, I., G. Henry, and E. Osborne. 1983. The Emotional Experience of Learning and Teaching. London: Routledge and Kegan Paul.

Santos, B.D.S. 2006. "The University in the 21st Century: Toward a Democratic and Emancipatory University Reform." In The University, State, and Market: The Political Economy of Globalization in the Americas, edited by R.A. Rhoads and C.A. Torres, 60-100. Palo Alto: Stanford University Press.

Santos, B.D.S. 2014. Epistemologies of the South: Justice against Epistemicide. London: Paradigm.

Sax, C., and D. Fisher. 2001. "Using Qualitative Action Research to Effect Change: Implications for Professional Education." Teacher Education Quarterly 28 (2): 71-80.

Smith, L., L. Bratini, D.A. Chambers, J.V. Jensen, and L. Romero. 2010a. "Between Idealism and Reality: Meeting the Challenges of Participatory Action Research." Action Research 8: 407-425. doi:10.1177/1476750310366043.

Smith, T., C. Edwards-Groves, and R. Brennan Kemmis. 2010b. "Renewing and Revitalising Educational Tradition: Resources for Action and Hope." Pedagogy, Culture and Society 18 (1): 1-103. doi:10.1080/14681360903556749.

Sparkes, A.C., and B. Smith. 2008. "Narrative Constructionist Inquiry." In Handbook of Constructionist Research, edited by J. Holstein and J. Gubrium, 295-314. London: Guilford Publications.

Storms, S.B. 2013. "Preparing Teachers for Social Justice Advocacy." Multicultural Education 20 (2): 33-39.

Thomas, L. 2000. “'Bums on Seats'; or 'Listening to Voices': Evaluating Widening Participation Initiatives Using Participatory Action Research." Studies in Continuing Education 22: 95-113. doi:10.1080/713695716.

Thomson, P. 2015. "Action Research With/Against Impact." Educational Action Research 23 (3): 309-311. doi:10.1080/09650792.2015.1062235.

Vaughan, M., and G. Burnaford. 2016. "Action Research in Graduate Teacher Education: A Review of the Literature 2000-2015." Educational Action Research 24 (2): 280-299. doi:10.1080/09650792.2015. 1062408.

Weber, E. 2011. "Transforming Higher Education: Action Research, Learning and Community Politics." Africa Education Review 8: 1-16. doi:10.1080/18146627.2011.286138.

Young, I.M. 2011. Justice and the Politics of Difference. Princeton, NJ: Princeton University Press.

Zeichner, K. 2010. "Competition, Economic Rationalization, Increased Surveillance, and Attacks on Diversity: Neo-Liberalism and the Transformation of Teacher Education in the US." Teaching and Teacher Education 20 (8): 1544-1552. doi:10.1016/j.tate.2010.06.004. 